\title{
EXPLORING THE IMPACT OF ECONOMIC GROWTH AND INFLATION RATE ON UNEMPLOYMENT IN INDIA
}

\author{
Sunita Kumari \\ PhD Scholar, University of Jammu
}

Article DOI: https://doi.org/10.36713/epra8489

DOI No: 10.36713/epra8489

\begin{abstract}
In India, it has been observed that after the Economic Reforms of 1991, the participation of labor force has increased marginally but the rate of unemployment has remained unchanged which still remains a matter of concern. On the other hand, India has faced the issue of persistent rise in prices which is another major problem. As both these parameters are vital measures of economic growth, this paper attempts to find the correlation between both these variables in the Indian context from the year 1991 to 2019. A. W. Phillips in his theory states that inflation and unemployment have a stable and inverse relationship. The major claim of the theory is that with economic growth comes inflation, which in turn should lead to more jobs and less unemployment. On the basis of Phillips Curve this paper attempts to analyze the effect of economic growth and Inflation on unemployment in India during the time period of 1991 to 2020. The observational findings revealed a negligible association between unemployment, inflation and economic growth in India.
\end{abstract}

KEY WORDS: employment, inflation, economic, growth, problem

\section{INTRODUCTION}

The Indian economy is facing the issues of persistent rise in prices and unemployment continuously for a number of years. In India, inflation, that is, the persistent rise in prices is measured on year to year basis on the basis of consumer price index and whole sale price index. The unemployment rate, on the other hand, is defined as the number of unemployed people as percentage of the total labor force. Further the Economic Growth of a country is measured in terms of growth in its Gross Domestic Product (GDP). Growth in GDP is the increase in the market value of all goods and services produced by an economy over a period of time.

The present study finds its theoretical basis in the Phillips curve, which is an economic concept developed by A.W. Phillips. The concept states that inflation and unemployment have a stable and inverse relationship. Also, the theory claims that with growth in GDP, inflation takes place which in turn leads to the creation of more jobs and less unemployment. On the basis of Philips Curve, this paper attempt to study the relation between unemployment, inflation and economic growth in India from the year 1991 to 2020.

\section{OBJECTIVES OF THE STUDY}

1. To find out the relationship between inflation rate and unemployment rate in India.

2. To find out the impact of Gross Domestic Product and Inflation rate on Unemployment rate in India.

\section{HYPOTHESES}

1. There is a negative relationship between Inflation and Unemployment.

2. Increasing Gross Domestic Product and Inflation rate decreases the Unemployment.

\section{METHODOLOGY}

The present study is based on secondary data. The data is collected from the official website of macrotrends and World Bank. Inflation rate is measured on the basis of consumer price Index. The Pearson's Correlation Coefficient technique is used to determine correlation between the variables inflation and unemployment. Stata software is used for 
calculations and to find out the impact of GDP and Inflation on Unemployment rate in India and statistical tool regression is used.

\section{REVIEW OF LITERATURE}

Samuelson and Solow (1960) in their paper supported the Phillips hypothesis for US supporting the negative relationship between unemployment and inflation. They were the first researchers to do so.

Mohseni and Jouzaryan (2016) in their paper examined the role of inflation and unemployment on economic growth from 1996 to 2012. They investigated the effect of inflation and unemployment on economic growth in two phases. The two phases were short-term and long-term phases. They model used in their study was Autoregressive Distributed Lag (ARDL) Model. The results shown by Model estimation confirmed the significant and negative effect of inflation and unemployment on economic growth in long term, which indicated that inflation and unemployment decreased economic growth in long term.

Alisa (2015) tried to figure out the relation between inflation and unemployment by analyzing different opinions of economists concerning the Philips curve by constructing short-term and long-term Philips curves (based on statistical data of The Russian Federation) by making some conclusions about the results at the end. The study concluded that from historical point of view, the connection between inflation and unemployment does exist.

Table 1 Unemployment Rate, Inflation Rate and GDP Growth Rate in India

\begin{tabular}{|c|c|c|c|}
\hline Year & Unemployment Rate & Inflation Rate & GDP Growth Rate \\
\hline 1991 & $5.55 \%$ & $13.87 \%$ & $1.06 \%$ \\
\hline 1992 & $5.61 \%$ & $11.79 \%$ & $5.48 \%$ \\
\hline 1993 & $5.72 \%$ & $6.33 \%$ & $4.75 \%$ \\
\hline 1994 & $5.75 \%$ & $10.25 \%$ & $6.66 \%$ \\
\hline 1995 & $5.75 \%$ & $10.22 \%$ & $7.57 \%$ \\
\hline 1996 & $5.75 \%$ & $8.98 \%$ & $7.55 \%$ \\
\hline 1997 & $5.74 \%$ & $7.16 \%$ & $4.05 \%$ \\
\hline 1998 & $5.74 \%$ & $13.23 \%$ & $6.18 \%$ \\
\hline 1999 & $5.78 \%$ & $4.67 \%$ & $8.85 \%$ \\
\hline 2000 & $5.75 \%$ & $4.01 \%$ & $3.84 \%$ \\
\hline 2001 & $5.73 \%$ & $3.78 \%$ & $4.82 \%$ \\
\hline 2002 & $5.77 \%$ & $4.30 \%$ & $3.80 \%$ \\
\hline 2003 & $5.77 \%$ & $3.81 \%$ & $7.86 \%$ \\
\hline 2004 & $5.72 \%$ & $3.77 \%$ & $7.92 \%$ \\
\hline 2005 & $5.65 \%$ & $4.25 \%$ & $7.92 \%$ \\
\hline 2006 & $5.52 \%$ & $5.80 \%$ & $8.06 \%$ \\
\hline 2007 & $5.41 \%$ & $6.37 \%$ & $7.66 \%$ \\
\hline 2008 & $5.36 \%$ & $8.35 \%$ & $3.09 \%$ \\
\hline 2009 & $5.61 \%$ & $10.88 \%$ & $7.86 \%$ \\
\hline 2010 & $5.65 \%$ & $11.99 \%$ & $8.50 \%$ \\
\hline 2011 & $5.65 \%$ & $8.86 \%$ & $5.24 \%$ \\
\hline 2012 & $5.66 \%$ & $9.31 \%$ & $5.46 \%$ \\
\hline 2013 & $5.67 \%$ & $11.06 \%$ & $6.39 \%$ \\
\hline 2014 & $5.60 \%$ & $6.65 \%$ & $7.41 \%$ \\
\hline 2015 & $5.56 \%$ & $4.91 \%$ & $8.00 \%$ \\
\hline 2016 & $5.51 \%$ & $4.95 \%$ & $8.26 \%$ \\
\hline 2017 & $5.41 \%$ & $3.33 \%$ & $6.80 \%$ \\
\hline 2018 & $5.33 \%$ & $3.95 \%$ & $6.53 \%$ \\
\hline 2019 & $5.27 \%$ & $3.72 \%$ & $4.04 \%$ \\
\hline
\end{tabular}

Source: World Bank

\section{ANALYSIS AND INTERPRETATION}

Table 1 shows the unemployment rate, inflation rate (Consumer Price Index) and GDP growth rate in
India from the year 1991 to 2019. It is observed from the table clearly that the unemployment rate in India 
from 1991 to 2019 has remained fairly consistent between 5 to $6 \%$.

On the other hand, we see in Table 1, that the inflation rate has varied over period of time significantly. The inflation rate in India in 1991 was $13.87 \%$ which came down to $6.33 \%$ in 1993 . But in the year 1994, it again crossed $10 \%$ mark and reached $10.25 \%$. After that, we see a consistently similar inflation rate till 2005 with the exception of 1998 when the inflation rate was $13.23 \%$. After 2005 till 2013, the inflation rate has shown an increase and it reached
$11.06 \%$ in 2013. But after 2014, the inflation rate in India decreased consistently till 2019 when it was 3.72 $\%$. Thus, the Table 1 clearly shows that the inflation rate has fluctuated between $3 \%$ to $14 \%$ throughout these years.

Further, when we see the GDP growth rate of India, we find that the Indian economy has seen an increase in GDP growth rate over the years. It was only $1.06 \%$ in 1991 but after that, it has grown consistently at around $6 \%$ to $7 \%$ on yearly basis. In 2019 the GDP growth rate was $4.04 \%$.

Figure 1 Unemployment Rate, Inflation Rate and GDP growth rate in India from 1991 to 2019

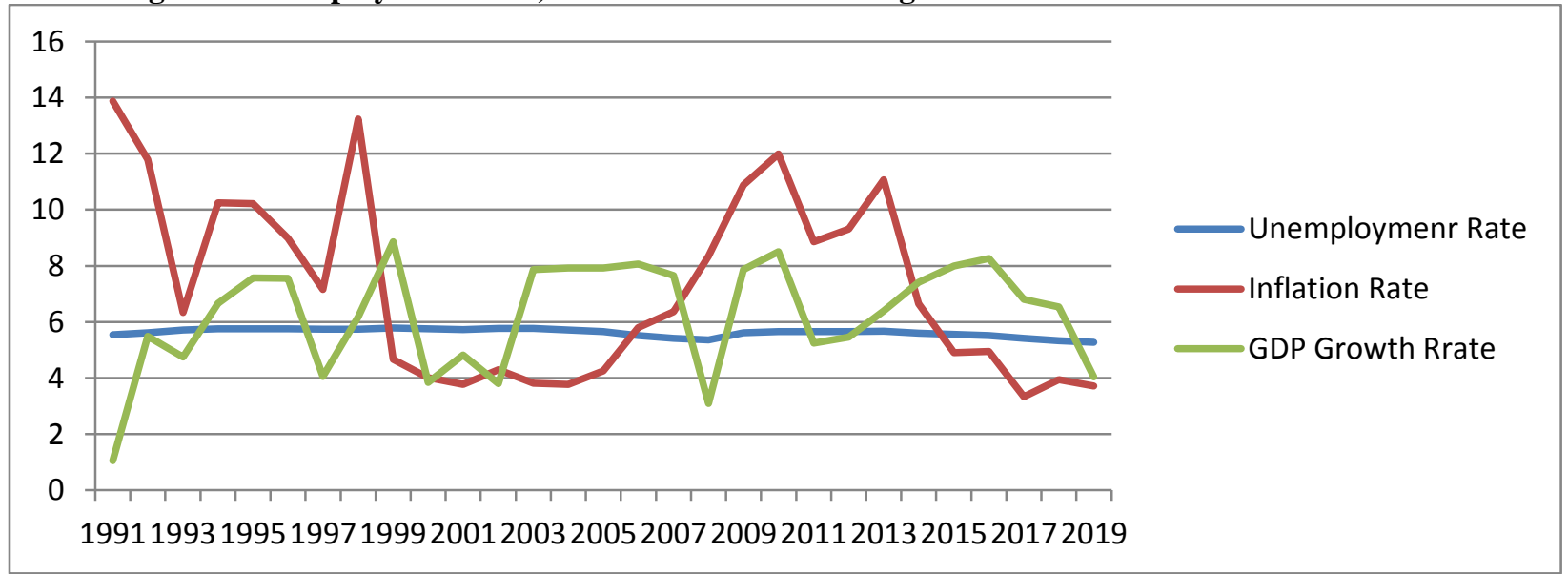

Source: Compiled by Author

It is seen in Figure 1 that unemployment rate in India has remained nearly same throughout the period but the inflation rate and GDP growth rate have shown variations. The inflation rate has come down when compared to 1991 and the Indian economy has shown GDP growth rates between $4 \%$ and $8 \%$ throughout the years.

By using the Pearson's Correlation Coefficient on Inflation and unemployment rate, the value of correlation coefficient comes out to be 0.05 , which shows only $0.05 \%$ positive relation between both the variables which means that there is negligible association between both the variables. Hence the Hypothesis that there is a negative relationship between Inflation and Unemployment is rejected.

On the other hand, GDP growth rate and Unemployment correlation is 0.11 , which also shows that there is negligible association between GDP and Unemployment. 
Table 2 Regression Analysis of Inflation, GDP and Unemployment
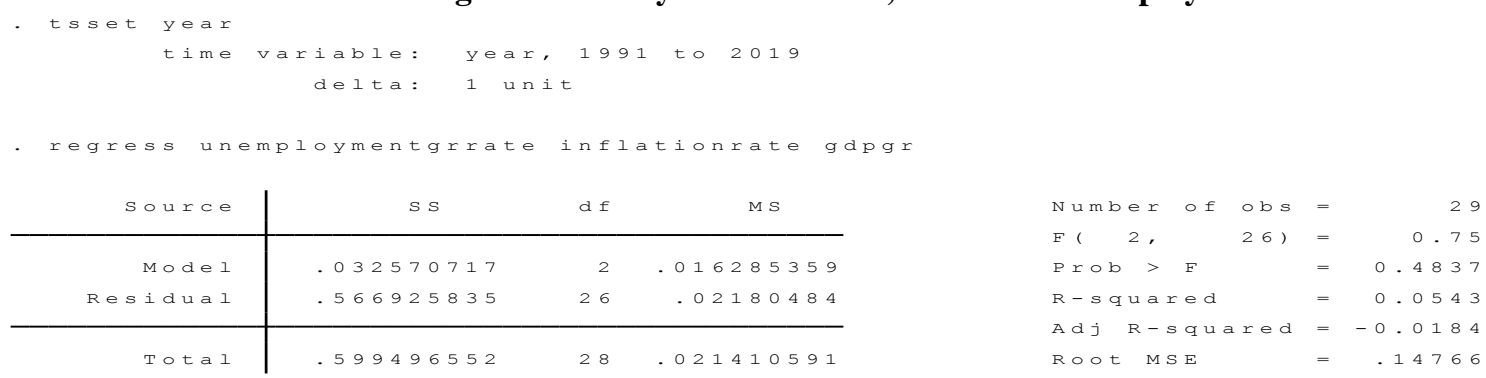

\begin{tabular}{|c|c|c|c|c|c|c|}
\hline unemploymen $\sim e$ & coef. & Std. Err. & t & $P>|t|$ & [ 95 웅 conf. & Interval ] \\
\hline inflationrate & .0090326 & .0086013 & 1. 05 & 0.303 & -.0086477 & .0267129 \\
\hline gdpgrate & .0116244 & .0146067 & 0.80 & 0.433 & -.0184 & .0416488 \\
\hline - cons & 5.481968 & .122373 & 44.80 & 0.000 & 5.230427 & 5.73351 \\
\hline
\end{tabular}

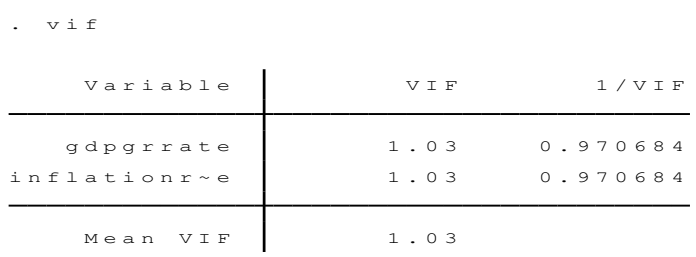

Source: Compiled by Author

In Table 2, in order to measure the impact of Gross Domestic Product and Inflation rate on unemployment in India, the statistical tool regression analysis has been used. In this case, there were $\mathrm{N}=30$ observations, so the DF for total is 2 . The independent variables are Gross Domestic Product and Inflation rate and unemployment is dependent variable.

\section{REGRESSION EQUATION}

unemploymentratePredicted

$5.481968+.0090326$ inflationrate +.0116244 gdpgr

The equation shows that for every unit increase in Inflation rate, the predicted value of unemployment would be +.0090326 units increased which shows that there is negligible association between them. In the case of other variable, for every unit increase in Gross Domestic Product, the predicted value of unemployment is .0116244 units increased which also shows negligible association between them.

Hence the second Hypothesis, that is, increasing Gross Domestic Product and Inflation rate decreases the Unemployment rate in rejected.

Karl Pearson's Correlation test shows that there is no correlation between inflation and unemployment rate in India in the short run and regression analysis states that with increase in inflation rate and increase in GDP growth rate, the unemployment is not reduced.

\section{CONCLUSION}

The present study was aimed at exploring the hypothesis referred by Phillips curve in the case of India during the time period of 1991 to 2019. The hypothesis suggested that Economic growth could have resulted in increase in Inflation rate and increased job opportunities for India, which ultimately could have led to reduced unemployment rate in the country, something that did not happen eventually in the Indian scenario. Many reasons could have caused this situation: high taxes, uncertainty in monetary policy, lack of investments, and continuous political corruption and non-existent political initiative. It is also seen in developing country like India that there is always a choice between labor intensive technology and capital intensive technology. Dealing with an ideal ratio between labor and capital in order to achieve the maximum output per unit of input, the labor will remain unemployed. India faces the problem of unemployment at the time of solving the problem of 'how to produce'. In consequence, India with high population will always provide more employment opportunities by opting labor intensive technology. Decentralization of Industrial activity, more Industries in co-operative sector, high rate of capital formation and more emphasis on vocational education can reduce the unemployment rate in India. 


\section{BIBLIOGRAPHY}

1. Samuelson, P.A. and Solow, R.M. (1960) 'Analytical aspect of anti-inflation policy', American Economic Review, Vol. 50, No. 2, pp.177-194.

2. Alisa, M. (2015) 'The Relationship between Inflation and Unemployment: A Theoretical Discussion about the Philips Curve' Journal of International Business and Economics, December 2015, Vol. 3, No. 2, pp. 89-97

3. Mohseni, M. and Jouzaryan, F. (2016) 'Examining the Effects of Inflation and Unemployment on Economic Growth in Iran (1996-2012)' Procedia Economics and Finance, Volume 36, 2016, Pages 381-389. 